ROCZNIKI FILOZOFICZNE

Volume LXVII, issue $4-2019$

DOI: https://dx.doi.org/10.18290/rf.2019.67.4-2

ANDRZEJ MARYNIARCZYK, S.D.B.

\title{
"PARVUS ERROR IN PRINCIPIO MAGNUS EST IN FINE": THOMAS AQUINAS'S REINTERPRETATION OF THE UNDERSTANDING OF BEING AND ESSENCE AS THE BASIS FOR THE DISCOVERY OF THE FIRST CAUSE AS IPSUM ESSE ${ }^{*}$
}

In metaphysics, we derive our knowledge about the First Cause of all things, that is God, His existence and nature, from cognition of really existing being, because God is not a direct (material) object of our cognition. Being and its essence are "those which are first conceived by the intellect." And thus, the intellect opens, as it were, the way for us to cognize the First Cause. That is why we can state that "everything about God's existence and nature that there is in our intellect was previously contained in being that was given to us in our sensory experience", which is a paraphrase of the principle of the metaphysics of cognition that says nihil est in intellectu quod non prius fuerit in sensu (there is nothing in the intellect that would not have been in the senses before). For this reason, Thomas Aquinas points out in his brief work entitled De Ente et Essentia that at the base of understanding the world, the human being, and God in particular, is our understanding of being and its essence. When we make a small mistake at the beginning (parvus error in principio) in our understanding of being and its essence, it will turn

Prof. Andrzej MaryniarczyK, S.D.B. - Professor of Philosophy at the John Paul II Catholic University of Lublin, Head of the Department of Metaphysics; address for correspondence e-mail: maryniar@kul.pl; ORCID: https://orcid.org/0000-0001-6535-5089.

${ }^{*}$ Translation of the paper into English and its proofreading was funded by the Minister of Science and Higher Education within the program under the name "Regional Initiative of Excellence" in 2019-2022, project number: 028/RID/2018/19, the amount of funding: 11742500 PLN.

${ }^{1}$ Thomas Aquinas, On Being and Essence, transl. Armand A. Maurer (Toronto, Canada: Pontifical Institute of Mediaeval Studies, 1965). Full text online: https://dhspriory.org/thomas/ DeEnte\&Essentia.htm, accessed August $11^{\text {th }}$ 2019, Proemium, no. 1. 
out to be a big one in the end (magnus in fine). And what is "at the end" of our knowledge is the discovery of the First and Ultimate Cause of all things, known as: Ipsum Esse, God, the Absolute, The Most Perfect Substance, on whom everything depends, and who depends not on anything else.

After taking into account this warning, it becomes clear to us why the problem of the correct understanding of being and its essence is what Thomas makes the subject of his inquiries. This "juvenile" treatise (De Ente et Essentia) will lie at the heart of Thomas's theodicy, which he will develop and supplement throughout his life. The inquiries about the proper understanding of being and its essence that will follow are aimed at formulating a proof of the necessity of existence of a Being that is the First Cause, and which, existing as Ipsum Esse, is the source and reason of existence of all beings. Without these inquiries, the proof itself would be incomprehensible, and more importantly it would be a purely a priori one (i.e., ontological). Furthermore, without the existential conception of being, which Thomas first formulated, one could not discover the First Cause which, as Ipsum Esse, is the source of the existence of every being. ${ }^{2}$ It should also be noted as an initial remark that Thomas, seeking a proper understanding of being and its essence, does so in the context of what had been developed earlier by Plato, Aristotle, Ibn-Sînâ (Avicenna), and Ibn-Rušd (Averroes). No wonder that in this treatise Thomas will redefine the understanding of being (ens) and essence (essentia) in relation to the previously existing one. Therefore, it is also a foreshadowing of the transition from the hylomorphic concept of being to the existential one, and from the understanding of essence (form) as a correlate of matter to essence as a correlate of existence. This will entail the need for further redefinitions of concepts such as: analogy, the concept of cognition (not in conceptus [concept] but in iudicium [judgment] percipit es$s e$ [we capture existence]), the concept (or theory) of causation (the theory of participation instead of the theory of four causes), and others. This problem seems to have escaped the attention of the author of the book Aquinas's Way to God. The Proof in "De Ente et Essentia." 3

It should also be noted that the specificity of the method of metaphysical explanation is that an objective (object-oriented) reason for the fact under

\footnotetext{
${ }^{2}$ More on this topic in: W. Seńko, "Wstęp [Introduction]," in Thomas Aquinas, Byt i istota [Being and Essence], transl. and comm. W. Seńko (Kęty: Wydawnictwo Marek Derewiecki, 2009), 13-24; Tomasz Sutton [Thomas of SutTon], De esse et essentia, transl. Piotr Kordula, introd. by Dawid Lipski (Warszawa: Wydawnictwo von borowiecky, 2018).

${ }^{3}$ Gaven Kerr, OP, Aquinas's Way to God. The Proof in "De Ente et Essentia" (Oxford: Oxford University Press, 2015).
} 
consideration is sought. The investigated fact are beings structurally composed of matter and form or form and existence, which due to this combination are contingent and unnecessary, and the ultimate reason for their existence is Being whose essence is its existence, conditioned by nothing whatsoever. Moreover, such analyses lay the foundations for philosophies of the theistic type, i.e. those in which the problem of God appears in a natural way and arises necessarily from the very knowledge and explanation of reality, and is not transferred from theology or religion. No wonder that the question of being and essence will become "the field of metaphysical investigations" of Thomas Aquinas. In this article, I will draw attention to this aspect of his analyses contained in the treatise De Ente et Essentia.

\section{REINTERPRETATION OF THE HYLOMORPHIC STRUCTURE OF BEING}

At the beginning of the first chapter, Thomas, referring to Aristotle, points out that "the word 'being', taken without qualifiers, has two uses, as the Philosopher says in the fifth book of the Metaphysics. (1) In one way, it is used apropos of what is divided into the ten genera; (2) in another way, it is used to signify the truth of propositions. The difference between the two is that in the second way everything about which we can form an affirmative proposition can be called a being [we can say that "it exists"], even though it posits nothing in reality. It is in this way that privations and negations are called 'beings' [it is being said that "they are"]; for we say that affirmation "is" opposed to negation, and that blindness "is" in the eye. In the first way, however, only what posits something in reality can be called a being. In the first way, therefore, blindness and the like are not beings." ${ }^{4}$ Thus, one can speak of being on two levels: the object-related (metaphysical) and the linguistic (cognitive), i.e. on the level of existence and on the level of cognition (predication), and when one does so, either way, being is spoken about in an analogous manner, and not unambiguously or ambiguously.

\subsection{From the ANALOGY OF ATTRIBUTION TO THE ANALOGY OF PROPORTION}

Thomas, referring to the above distinction contained in the fifth book of Metaphysics and concerning the way of speaking about being, indirectly re-

\footnotetext{
${ }^{4}$ Thomas Aquinas, On Being and Essence, Cap. 1, no. 4.
} 
fers to the text from the fourth book of Metaphysics, in which Aristotle himself explains that "There are many senses in which a thing may be said to "be," but all that "is" is related to one central point, one definite kind of thing, and is not said to "be" by a mere ambiguity. ... Some things are said to be because they are substances, others because they are affections of substance, others because they are a process towards substance, or destructions or privations or qualities of substance, or productive or generative of substance, or of things which are relative to substance, or negations of one of these things of substance itself."

From these statements, we learn that both the word "being" and being itself should be understood in an analogous way. ${ }^{6}$ Here we meet the first element in the overall understanding of being that will be reinterpreted, namely the analogy applied to how being is conceived of. In Aristotle's case, this analogy was the analogy of attribution (attribution to one - Gr. $\pi \rho$ ò [pros hen], namely to a substance). Being in the proper sense is that which we call a substance or that which is attributed to a substance (properties, relations, processes, actions). Substance is therefore this particular, main analogate of being, the knowledge of which is a guarantee of correct predication about other things as beings. Just as predicating about an apple, water or air that they are healthy first requires knowledge about what health means. This primordial knowledge of substances and health, assumed in the analogy of attribution, contains some a priori elements. For how can we acquire any knowledge of being before cognizing (predicating)?

But Thomas, accepting analogy in the understanding of being, follows a different path. Being, in its first and basic sense, is not so much that which is a substance as that which consists of the essence and proportional act of existence. Thus, the analogy to which Thomas will refer will be the analogy of the proportions that occur between the intra-being elements: essence and existence. It is thanks to the perception of this relation of the essence to the existence (which is a necessary relation) that something is a being and we can call that thing "a being." In contrast to the predication in the analogy of attribution, we do not assume the knowledge about the main analogate, be-

\footnotetext{
${ }^{5}$ Aristotle, Metaphysics, transl. W.D. Ross, Adelaide: University of Adelaide Library, 2000 [IV, 1003a, 31-1003b, 10 of the original text], https://ebooks.adelaide.edu.au/a/aristotle/metaphysics/book4.html, accessed August $11^{\text {th }}, 2019$.

${ }^{6}$ The structure of analogy is formed by analogate, analogon(s) and common property. Referring to the categories distinguished by Aristotle, one should point to the substance as the main analogate, while the analogons will be the accidents ( 9 categories of being), and the common property is that they exist (either in themselves or in something [that exists]).
} 
cause we only formulate our basic understanding of this analogate as something in which there is a necessary relation between the essence and existence. For the combination of essence and existence is the reason of calling something "being" and the real existence of things.

\subsection{From the Hylomorphic to the EXISTENTIAL CONCEPT OF BEING}

The second element subject to Thomas's reinterpretation is the shift of the hylomorphic concept of being towards the existential concept. ${ }^{7}$ This "procedure" is very important and will decide in a fundamental way on reaching a new understanding of the First Cause as Ipsum Esse. Thomas points out that matter and form are not the reason of existence of being as being, because form determines being to a specific way of existence, but does not make it exist. "For through the form - Thomas explains - which is the actuality of matter, matter becomes something actual and something individual. Whence what supervenes does not confer on matter actual existence simply, but such an actual existence as accidents in fact do. ... Whence the acquisition of such a form is not called generation simply, but generation in a certain respect." 8

Thomas therefore draws attention to the fundamental weakness and insufficiency of the hylomorphic theory of existence and modifies it in a fundamental way towards the existential concept. For existence does not exist thanks to matter and form, as Aristotle believed, because neither form nor matter brings with it an act of existence. If form does not bring existence, and neither does matter, then the question arises: why do beings exist? This is how the existential concept of being is born in Thomas's mind. For Aristotle, this was not a problem, because he accepted (a priori) the eternal existence of the first matter, the heavens and the First Mover. ${ }^{9}$ For this reason, in the hylomorphic structure of existence, matter carried with it the existence, and the form organized this matter into a specific kind of existence.

\footnotetext{
7 "Thomas, through some intuition that is unique in the entire history of philosophy, saw the nature of being in a proper (as we think) manner - Krąpiec writes. - And in the light of this vision he sketched out [in De Ente et Essentia - A.M.] a program of the total rebuilding of philosophy. At the same time, he used old, commonly known terms, but he put new content under these old, Aristotelian or neo-Platonic terms." Mieczysław A. KrĄPIEC, Metafizyka. Zarys teorii bytu [Metaphysics. An outline of the theory of being] (Lublin: TN KUL, 1978), 404

${ }^{8}$ Thomas Aquinas, On Being and Essence, Cap. 1, no. 18.

${ }^{9}$ For further reading see KRĄPIEC, Metafizyka [Metaphysics], $402 \mathrm{f}$.
} 
What Aristotle thought of as being-substance, namely the combination of form and matter, Thomas reduces to the essence and explains that "the word 'essence' in composed substances signifies that which is composed of matter and form." 10

Thus, Thomas reinterprets the hylomorphic concept of being and goes in the direction of the existential concept. Although the statement that being consists of form (essence) and existence appears only when discussing nonmaterial substances, namely the soul and intelligence, it is only here that we can clearly see that we cannot identify the act of form with the act of existence, which in the understanding of material beings is not clearly visible. For in material beings composed of matter and form, form was identified with an act that organizes matter into a particular being. Meanwhile, the form does not confer on matter "actual existence simply, but such an actual existence as accidents in fact do."11 For this reason, the analysis of nonmaterial substances (soul and intelligence) makes it possible to show this more clearly, for "there is in no way a composition of matter and form in the soul or in an intelligence if matter in them is taken in the sense in which matter is taken in corporeal substances. But there is in them a composition of form and existence."12 Asking about the essence of separated substances such as soul and intelligence, Thomas notes that these substances are composite, in contrast to the First Cause, the Absolute, because otherwise they would be pure (independently existing) forms. However, he rejects the view of Solomon ibn Gabirol (Avicebron) that the soul and intelligence are composed of matter and form. The argument Thomas makes is the fact that these substances have the ability to cognize. ${ }^{13}$ Such substances (forms), he explains, "are not actually intelligible except according as they are separated

\footnotetext{
${ }^{10}$ Thomas Aquinas, On Being and Essence, Cap. 1, no. 18.

${ }^{11}$ Ibid.

${ }^{12}$ Ibid., Cap. 3, no. 70f. In the footnote to this text, in the Polish edition of De Ente et Essentia, we find such a comment of Krapiec: "Thomas is the first to formulate the theory of being composed of a concrete essence (potency) and existence (act). This is a revolution in the understanding of reality. From now on, the contingency of being is understood as the non-necessity of existence. Hence, only one being, the First Being — the Absolute - is not composite and therefore non-relative, and everything else is endowed with a relational unity of existence and essence. Thomas's theory of being, always maintained by him, was misinterpreted in the history of philosophy due to the balancing out of the components of being, due to erroneous theoretical and cognitive assumptions (the tendency to encase the whole of cognition in concepts), and due to a priori, systemic reasons." St. Thomas Aquinas, O bycie i istocie [On being and essence], transl. Mieczysław A. Krąpiec (Lublin: RW KUL, 1994), ch. 4, p. 30, footnote 46.

${ }^{13}$ Thomas Aquinas, On Being and Essence, Cap. 3, no. 67.
} 
from matter and from its conditions; nor are they made actually intelligible except by the power of a substance understanding them, according as they are received into, and are affected by, that substance." 14 Therefore, matter cannot be present in such substances, because matter, determinate (signata) as well as indeterminate (non signata), if from necessity it was connected with every form, would stand in the way of cognition. For "the corporeal form itself, just as other forms, is actually intelligible according as it is abstracted from matter. Whence there is in no way a composition of matter and form in the soul or in an intelligence if matter in them is taken in the sense in which matter is taken in corporeal substances. But there is in them a composition of form and existence." 15 Thomas refers here to the commentary on the ninth proposition of the Book on Causes, from which we learn that "«an intelligence is something having form and existence», and form is taken there for the simple quiddity or nature itself." 16

This is an important step in the formation of a new, existential concept of being instead of a hylomorphic one. Thomas's next step in the formation of the existential concept is to determine the relationship between essence and existence in separated substances (soul and intelligences) and the existential status of such substances. Thus, we read the following: "It is easy to see how this may be so. Whatever things are so related to one another that one is a cause of the other's existence, the one which is the cause can have existence without the other, but not conversely. Now the relation of matter and form is such that form gives existence to matter. It is impossible, therefore, that matter exist without some form. But it is not impossible that some form exist without matter." ${ }^{17}$ So, there are forms that can exist in separation from matter. However, these forms, due to the impossibility of them being the source of themselves, cannot be the causes of their own existence. For they do not carry with them the act of existence as such, but only the act of "being this particular thing." 18 Thomas sees the reason of not connecting the form with the act of existence in the structure of both material and nonmaterial beings in the distance between the form and "the first principle [source], which is the first and pure [unmixed] act."19

\footnotetext{
${ }^{14}$ Ibid., no. 68.

${ }^{15}$ Ibid., no. $70 \mathrm{f}$.

${ }^{16}$ Ibid., no. 71 .

${ }^{17}$ Ibid., no. 72.

${ }^{18}$ Ibid., Cap. 1, no. 18.

${ }^{19}$ Ibid., Cap. 3., no 72.
} 
So the question arises: what does this "distance from the first principle" mean? The expression "distance" indicates that the form thus understood is not the first act of a [particular] being, but its second (secondary) act which makes it "this particular thing." Thus understood, the second act acts by virtue of the first act, which is "the first and pure [unmixed] act." Thus, we can see the existential weakness of the hylomorphic structure of being, which needs to be complemented by the act of existence that is transcendent to (or: unmixed with) this structure. ${ }^{20}$ What is more, also in substances separated from matter (souls and intelligences) we cannot identify the act of existence with the form. "The formation of content is always related to existence and is carried out "under" [the rule of] existence"-Krąpiec explains. ${ }^{21}$ And although existence does not bring "any content to the essential structure, it has a total impact on it, because the whole essence is formed depending on that existence. Under and with the actual existence, the essence of a thing arises, and in no way does it precede existence in all that which is real. [...] In fact, there is no single element, even the smallest one-whether substantial or accidentalthat would not be created in total dependence on existence. Existence in being is therefore the justification for the whole being-ness of [all] things; it is [also] the basis for explaining those things. It is the most perfect thing." 22

This discovery by Thomas, concerning the composition of both material and separated substances from the essence and existence, has the characteristics of a "revolution," because it indicates that the world and beings are contingent, i.e. not necessary in their existence. The set of such beings, which are contingent and have no reason of their existence in themselves, does not explain the existence of the world. Therefore, it is necessary to start searching for a new source of the existence of beings, namely such a Being whose essence is existence, and which has endowed beings with what they do not possess on their own, that is, existence, being the First and unconditional Existence itself-Ipsum Esse.

This will be the starting point for Thomas to discover a new First Cause of beings, namely the cause of existence, called the Creative Cause, and to formulate in the future a metaphysical theory for the creation of the world ex nihilo.

We can draw a few conclusions from the above analyses: Firstly, the term "existence" as well as being itself is understood by Thomas in an analogous manner. For this reason, the first and basic understanding of being is a

\footnotetext{
${ }^{20}$ Cf. KRĄPIEC, Metafizyka [Metaphysics], 403.

${ }^{21}$ Ibid., 405.

${ }^{22}$ Ibid., 455.
} 
substance, i.e. such a being that exists independently and exists within itself (but not by itself), and is the subject for accidents and the source of action. Secondly, the term "being" has a broader scope than the term "substance". With the term "being" we can refer to accidents, relation, process, action, but also to an affirmative statement. However, in the basic sense the term "being" means that which is based in a [real] thing, and in the first sense it is substance, that is, something that exists on its own and independently. In turn, the term "substance" means only that which exists within itself, and is the subject of accidents and the source of action. Thirdly, according to Aristotle, the structure of material being consists of matter and form. However, neither matter nor form cause the existence of being as such. Yes, we associate the causative factor of being with the form, but the form is the efficient cause of a specific way of existence of a being (this particular being!), and not the cause of its existence in general. Thus, in the hylomorphic concept of being, as well as in the essential concept of being (intelligences, pure forms), beings do not carry the reason for their existence within themselves. Fourthly, the hylomorphic concept of existence, as well as the essential one (intelligences), must be complemented by an existential concept, which was exactly what Thomas did, and which is a sine qua non condition for the conception of God as Ipsum Esse. Fifthly, the act (fact) of existence escapes the definition and conceptual approach. No wonder, therefore, that the analyses of how composite beings were cognitively approached and defined in Aristotle's epistemology could not end with the discovery of the act of existence.

\section{REINTERPRETATION OF THE UNDERSTANDING OF ESSENCE}

Turning to the understanding of the essence, Thomas warns at the very beginning that the name "essence" cannot be referred to beings in the meaning of cognitive constructs: concepts or clauses. "Some things which do not have an essence are called beings ... as is clear in the case of privations. Rather, the word "essence" is taken from the word "being" used in the first way [substance and categories - A.M.]." 23 This text is explained by Krąpiec in the following manner: "then the substance, as the object of cognition aimed at defining it, is the "essence" in the original sense. In the derived sense, "essence" is also everything that is accepted in cognition as some "subject",

\footnotetext{
${ }^{23}$ Thomas Aquinas, On Being and Essence, Cap. 1, no. 5.
} 
as long as it is definable." ${ }^{24}$ Krapiec refers here to the distinction made by Aristotle in the Categories, namely between the first substance (Gr. ovjoía

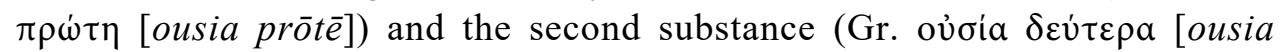
deutera]). ${ }^{25}$ The first substance is a concrete, or, in other words, a particular subject for accidents, while the second substance is a definition of what is individual in its species or in its genus (i.e. the approach to John as a human being or John as a rational animal) and performs the function of the subject for predicates in a sentence.

Thomas recalls and explains his understanding of being that he spoke about earlier, which is divided into 10 categories, but the category of substance is the first and basic among them all. All the other categories are related to being in the analogous sense. The same will apply to the understanding of the essence. We must also understand it in an analogous way. Because, as Thomas writes: "The word "essence" must signify something common to all natures, by means of which (nature) diverse beings are placed into diverse genera and species; as, for example, humanity is the essence of man." 26 The question arises, therefore, what is the first and fundamental meaning that we can treat as the main analogate? In response, Thomas explains that by essence we mean "that by which a real thing is constituted in its proper genus or species [and that which] is signified by the definition expressing what the real thing is, [hence] philosophers sometimes use the word "quiddity" for the word "essence." This is what the Philosopher often calls

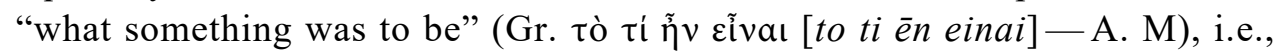
that by which it belongs to something to be what it is." ${ }^{27}$ For this reason, Thomas continues, it can also be called form, "in the sense in which the word "form" signifies the full determination [certitudo] of each real thing." 28 It can be called nature, "according as it has an ordering to the thing's proper operation," ${ }^{29}$ substance, understood as a subject for accidents, and also quiddity, which is signified by the definition of a thing, i.e., essence, provided that "through it and in it a real being has existence." ${ }^{30}$ Thus, also here, on the

\footnotetext{
${ }^{24}$ Tomasz z Akwinu [Thomas Aquinas], O bycie i istocie [On being and essence], ch. 1, p. 10 , footnote 6 .

${ }^{25}$ ARIStotle, Categories, transl. E.M. Edghill, Adelaide: University of Adelaide Library, 2015, No. 5 [2a, 11-19 of the original text], https://ebooks.adelaide.edu.au/a/aristotle/categories/, accessed: August $11^{\text {th }}, 2019$.

${ }^{26}$ Thomas Aquinas, On Being and Essence, Cap. 1, no. 6.

${ }^{27}$ Ibid., no 7.

${ }^{28}$ Ibid., no. 8 .

${ }^{29}$ Ibid., no 10 .

${ }^{30}$ Ibid., no 11.
} 
one hand, Thomas refers to the analogy of attribution (Gr. $\pi \rho$ ò hen]) as a result of which the form/nature/substance/quiddity can be called "essence" (provided that they signify "that through which and in which a real being has existence"), while, on the other hand, his approach to essence shifts in the direction of the analogy of proportion, when he proves that in composite substances the structure of being consists of matter and form (as they determine these beings in their entirety).

Looking for an answer to the question of what constitutes the essence of composite material substances and what constitutes the essence of separated substances (soul and intelligences, and also God), Thomas leads us to understand essence as a correlate of existence. This is why he points out that the Latin word essentia comes from esse and indicates something that belongs to the order of existence. In Polish, therefore, the words "essence" (istota) and "existence" (istnienie) should be understood in the same way as the words signifying "work/labor/job" and "doing" (robota and robienie) which reflect the same activity, the same order if you will, namely the order of makin$\mathrm{g} /$ accomplishing/facilitation. No wonder that essence is something that exists and has been made/accomplished/facilitated, just like there is work (or labor, or a job) and doing that makes this work done. ${ }^{31}$

The main question Thomas wants to ask is not so much a question about being as a question about the essence of being. Why is it so important? Because the essence reveals the ultimate truth about being's existence: it indicates "what thing [i.e. being] is", "thanks to which something exists." For this reason, Thomas directs the main course of his investigations towards searching for such an essence that represents the entirety of being and is the reason of every particular (this and that) existence.

\subsection{The ESSENCE OF COMPosite SubStanCES}

Starting with a question about the essence of what is composite, Thomas invokes the hylomorphic structure of beings. However, in his answer to the question "what is the essence of that which is composite," he does not seem to follow Aristotle entirely. For in the hylomorphic composition, it was form that represented the essence of being. Form was also "that thanks to which something is what it is" and "what is signified by the definition of a thing." But at the very beginning, Thomas makes a reservation that "we cannot say

\footnotetext{
${ }^{31}$ This is discussed in more detail in SEŃKO, "Wstęp [Introduction]," $22 \mathrm{ff}$.
} 
that either one of them alone may be said to be the essence." 32 Why? Because neither matter itself, nor the form itself, constitute "what something was to be." Thomas cites as an argument the fact that essence referred to in the "definition of natural substances [i.e. those of natural world] contains not only form, but matter as well; otherwise natural definitions and mathematical ones would not differ." 33 Therefore, it is not possible to identify essence with form. Moreover, essence is not "some relation between matter and form" (or body and soul) either. Why? Because, first of all, relation belongs to the category of accident, and if that was the case, essence would necessarily be an accident or something quite different than the thing itself, and therefore the thing would not be cognized and defined through the knowledge of such an essence. Therefore, Thomas will conclude, "it is clear that essence includes matter and form." 34 Thus, the structure of essence in composite beings consists of both matter and form. However, the question immediately arises: but thanks to what does such an essence exist?

Here, after the analogous understanding of essence, the second element of the new interpretation of essence appears, namely conceiving of it not as a correlate of matter, but as a correlate of existence. Why? Because through form, matter becomes an actual being, albeit "this particular being" only. What is added to the matter (that is, form) does not endow the matter with the actuality as such but only the act of being "this particular thing", similarly to what accidents do. The acquisition of a form does not signify generation of a being (the act of being as being), but ,generation in a certain respect." 35 Here Thomas emphasizes the need to distinguish between generation as an accidental activity, which involves the acquisition or loss of form, and generation as an absolute activity, which involves the introduction of being into existence.

Thomas also refers to the opinion of Boethius, Avicenna and Averroes to confirm his position, and finally to the cognitive obviousness, saying that "Reason, too, is in accord with this, because the existence of a composed substance is not the existence of the form alone nor of the matter alone, but of the composite itself; and essence is that according to which a real thing is said to be. Whence it is necessary that the essence, whereby a real thing is denominated a being, be neither the form alone nor the matter alone, but

\footnotetext{
${ }^{32}$ Thomas Aquinas, On Being and Essence, Cap. 1, no. 15.

${ }^{33}$ Ibid., no. 16.

${ }^{34}$ Ibid., no. 17.

${ }^{35}$ Ibid., no. 18.
} 
both, although the form alone in its own way is the cause of such existence." ${ }^{, 36}$ For that reason, Thomas will make it clear that "the word "essence" in composed substances signifies that which is composed of matter and form ${ }^{, 37}$ and therefore essences cannot be something general like a species or a genus. ${ }^{38}$

This composition of essence (involving both matter and form), however, is not to be understood as an aggregate of two elements - as if, for example, human being were composed of an animal and rationality, body and soul but as a third thing: a rational animal. It is "not as a third thing out of two other things, but as a third concept out of two other concepts," 39 just as the concept of genus and the concept of specific difference make up the concept of species or a definition that can predicate on an individual (and composite) being as a whole in an approximate manner. Thomas points this out, explaining that "just as that which is a genus, as predicated of the species, implies in its signification, though indistinctly, everything that is determinately in the species; so too that which is a species, according as it is predicated of the individual, must signify, though indistinctly, everything which is essentially in the individual. And it is in this way that the essence of the species is signified by the word "man"; whence man is predicated of Socrates."

This lecture by Thomas on understanding the essence of composite things is very important and binding for his new understanding of being, which he formulates having Aristotle and hylomorphism as his point of departure. The essence of which Thomas speaks expresses and captures a whole that is composed of matter and form (soul and body), but not in the sense of sum-

\footnotetext{
${ }^{36}$ Ibid., no. 20.

${ }^{37}$ Ibid., no. 18.

${ }^{38}$ As an argument, Thomas points out that, first of all, both species and genus are not essences. They both only indicate essence (because they are captured in the definition and introduce the order of existence) which envelopes being [i.e. a thing] in its entirety, matter and form. Secondly, just as the definition of Socrates includes determinate matter (signata) that individuates him but at the same time is a part of the indeterminate matter (non signata) that is included in the definition of human being, so part is included in the whole and the whole permeates parts - just like a genus does in a species and a species in a genus. Essence, therefore, always concerns a concrete, individual being, because "the genus, the difference, and the species are related proportionately to the matter, to the form, and to the composite in the real world, although they are not identical with them. The genus is not the matter, but taken from the matter as signifying the whole; nor is the difference the form, but taken from the form as signifying the whole. Whence we say that man is a rational animal, and not that man is made up of animal and rational as we say that man is made up of soul and body." Ibid., no. 35-37.

${ }^{39}$ Ibid., no. 37.

${ }^{40}$ Ibid., nos. 43-44.
} 
mation, but in the sense of synthesizing: just as a third autonomous concept is created from two other ones which, although separate, are virtually contained in it.

However, by identifying essence with the entirety of a composite being (because its structure includes matter and form), the "weakness" of such an essence is revealed, namely the lack of reason of the act of existence, thanks to which that being actually exists. Thus, Thomas opens a new understanding of essence to the need of its correlate, which is the act of existence. In this way, essence also obtains a new, namely existential (re)interpretation as a correlate of existence. For in the hylomorphic structure of being, the correlate of the essence-form was matter. ${ }^{41}$ Hence Krąpiec, explaining Thomas's great discovery concerning the existential concept of being, adds that "the essence and existence as potency and act are in the same category of being. Thus, if an essence is in the category of substances, then existence also belongs to the same category (reducitive), and if an essence belongs to the category of accidents, then existence also belongs to the same category. It is dependent on the nature of a given category (relationship, quantity or quality, action or sensation) that the essence itself and existence are realized." ${ }^{42}$ Thus, if a being is a human, or an animal, or a plant, then it will have the existence proportional to its essence: human, animal, or plant existence, etc. The same applies to the accidents that occur in these beings (e.g.: the accidental existence of John's nose, because it does not exist by its own existence, but by virtue of the existence of John). This explanation confirms that the relationship of being to existence is a transcendental relation and applies to every composition that there is in being; it confirms the existential structure of being and indicates its contingent nature.

\footnotetext{
${ }^{41}$ These analyses concerning the "structure" of essence [of composite beings] are complemented by an attempt to answer the questions of how essence is related to species and genus. Well, species, genus, and the difference are cognitive apprehensions of what is individual and composite. They are constructions of the intellect that abstracts them from things. These concepts are all related to essence, but not in a manner that is constitutive to it (like matter and form), but accidental. The concepts of species, genus, and specific difference, i.e. concepts such as man (humanity), animal (animality), and rationality, belong — as constructs of intellect — to the order of cognition. And once the essence of a being is conceived of as composed of matter and form, they are contained in this essence in the accidental manner, and in the same manner they modify this individual essence of, say, Socrates, encompassing his humanity, animality, and rationality.

${ }^{42}$ KrĄPIEC, Metafizyka [Metaphysics], 407.
} 


\subsection{The Essence of Separated Substances (Beings)}

Thomas then asks about the essence of separated substances such as the soul, intelligences and God (First Cause), aiming to show the potential character of essence. However, only God is a simple substance (meaning: noncomposite), while souls and intelligences, not being God, must be composed in some way. But the question arises, what are these beings, and what is their essence? In composite substances, as it was shown above, matter and form made up the structure of essence, while in the case of souls and intelligences, as Thomas explains, "It is not necessary that the essences or quiddities of these substances be other than form itself. Thus the essence of a composed substance and that of a simple substance differ in this: the essence of a composed substance is not form alone, but includes form and matter; the essence of a simple substance is form alone."

Therefore, in the case of immaterial substances (souls and intelligences), we associate the essence with the form alone, which represents the whole of such a being. Hence, the essence of a non-composite thing (where there is no matter) is the non-composite thing itself, because "nothing is there besides the form as receiving the form." 44 The question arises, however, what kind of a whole is it? Is it an essential whole or an existential whole? Thomas's answer will lead to another reinterpretation, namely the reinterpretation of the form. In the case of separated substances, such as intelligences, form does not function as an act, but as a potency-related factor. Otherwise, this form would constitute a pure, self-contained act. In the case of composite beings, the form acquired this potential character because of the matter.

Having this in mind, Thomas remarks that such non-material substances "are not utterly simple." 45 If so, they would be, again, pure acts. What are their characteristics, then? In response, we learn that "they have an admixture of potency." ${ }^{46}$ Potency, as Thomas explains, is the reason for the differentiation of intelligences. Hence, intelligences differ in their degree of perfection as long as they move away from potentiality and closer to the pure act. $^{47}$ Their genus can be identified by their degree of non-materiality (e.g.

\footnotetext{
${ }^{43}$ Thomas Aquinas, On Being and Essence, Cap. 3, no. 72 f.

${ }^{44}$ Ibid., no. 74

${ }^{45}$ Ibid., no. 76 .

${ }^{46}$ Ibid.

47 "The separated substances, therefore, are distinct from one another according to their grade of potency and act, in such a way that a superior intelligence which is nearer to the First Being has more act and less potency, and so with the others." Ibid., no. 84.
} 
their intellectual character), and the specific difference (although unknown to us) "is taken from that in them which follows upon their grade of perfection." ${ }^{48}$ However, the question arises, how do such beings relate to existence?

\subsection{NON-IDENTITY OF ESSENCE AND EXISTENCE}

This issue affects the very core of philosophy in general and the philosophy of St. Thomas in particular. For it is about the very structure of being and the indication of that thanks to which things exist. ${ }^{49}$

In order to explain this and to find a way to show the non-identity of essence and existence in non-material (yet composite) entities, Thomas reinterprets the Aristotelian concept of cognition. In Aristotle's theory of cognition, we captured the whole of being by capturing its essence (thanks to metaphysical abstraction-abstractio totalis). This essence and at the same time the whole of being was represented by form. This was the so-called second

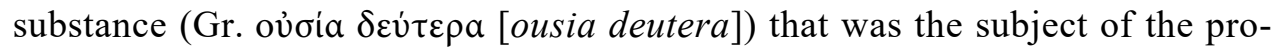
cess of predication, in which the process of cognition was manifested as consisting in combining or dissociating concepts with the subject of predication.

Thomas, referring to the acts of cognitive apprehension of essence, points out that in the approach aiming at the definition of the essence of being, we do not perceive the whole of being. What, then, is missing from this whole being? The act (fact) of existence has not been approached at all. Hence, he explains that "Whatever is not of the understood content of an essence or quality is something which comes from without and makes a composition with the essence, because no essence can be understood without the things which are parts of it. Now, every essence or quiddity can be understood without anything being understood about its existence. For I can understand what a man is, or what a phoenix is, and yet not know whether they have existence in the real world. It is clear, therefore, that existence is other than essence or quiddity, unless perhaps there exists a thing whose quiddity is its existence." 50

In a footnote to this text, Krąpiec explains: "This is the famous proof of non-identity of a concrete essence and existence in being. Taken in negative form, it shows the contradiction of the identity of existence and essence, because in such a case (if existence and essence were really one and the

\footnotetext{
${ }^{48}$ Ibid., Cap. 4, no. 96.

${ }^{49}$ This is discussed in more detail in KrĄPIEC, Metafizyka [Metaphysics], $413 \mathrm{f}$.

${ }^{50}$ Thomas Aquinas, On Being and Essence, Cap. 3, no. 77.
} 
same!), however many times we comprehended the essence and figured out the characteristics of this essence, so many times they would exist, and this is contradictory, because abstracts do not exist and cannot exist." ${ }^{51}$ Krąpiec also points out that in proving the real difference between essence and existence, we can distinguish two types of justifications: direct and indirect. In the first case, we demonstrate this difference by referring to the analysis of cognitive approaches to essence, as well as the analysis of functions performed by the act of existence in being. However, this type of proving - in which we draw certain conclusions from the fact that in the cognitive approaches to the essence of being we do not capture its existence - may be met with the objection that we shift from the cognitive order to the order of existence (de posse ad esse non datur illatio - from what is potential there is no transition to what is real). And this [let us repeat] is because we conclude that there is a real difference between essence and existence based on the fact that in the cognition of essence, we do not apprehend existence. Many things can be thought of, and yet not all of them exist, because our cognitive approaches do not yet create really existing beings. That is why Krapiec proposes to transform this proof into its negative form, according to the principle: a non posse ad non esse valet illatio - there is transition from the impossibility of existence to non-existence. So if we conclude that something is "contradictory and absurd in the order of thinking, it is just as absurd in the order of existence." 52 And such a thing would happen if our apprehension of existence accompanied our apprehension of essence. Abstracts and mental constructs would then exist as real beings. There would be a human being as such, but it would not be possible for multiple people to exist, nor would such a human being be bad, nor good, nor big, nor small, and so on. ${ }^{53}$

The analysis of conceptual cognition, on which Aristotle's epistemology was built, makes us aware that we do not include in it something most important of being, namely the act of its existence. For Aristotle this was not an issue, because the form was captured in the concept as an act of existence of a being. However, Thomas pointed out that the form understood in this way (reached and grasped through metaphysical abstraction) is not an apprehension or representation of the prior act, which is the act of existence. Instead, in this approach, the posterior act is captured; the act which makes

\footnotetext{
${ }^{51}$ Tomasz z Akwinu [Thomas Aquinas], O bycie $i$ istocie [On being and essence], ch. 4, p. 32 , footnote 47 .

${ }^{52}$ KrĄPIEC, Metafizyka [Metaphysics], 415.

${ }^{53}$ This is discussed in more detail in ibid., $415 \mathrm{f}$.
} 
a being "such being" or "this particular one" (John, Socrates, etc.). Hence, his intuition will appear, which in time will be clarified, that iudicium percipit esse rei - it is in (existential) judgment that we approach and grasp the existence of things, not in concept.

Krąpiec supplements this proof from the analysis of the cognitive apprehension of essence with the analysis of the function of existence in being and presents it as follows:

"If to be (real), to live, to exist, is an existential perfection, then to be (real), to live, to exist, is an act of a being. Therefore, existence of things is an existential act.

"The existential act, since it is not in potency in the slightest, is not connected with anything in the manner of potency. Therefore, existence as such is not connected with anything in the way of potency.

"The existence which is not connected with anything, and to which nothing can be added because of that, is the existence that is one, not distinguished from others.

"But at the same time we note that there are multiple existences in the natural world. Therefore, the fact of the multiplicity of existences indicates that being is not only existence, but it has another element, something that is not existence. This something we call essence. Therefore, in plural beings, we distinguish at least two different elements, which are not really identical: existence and that real something that is not existence ${ }^{54}$ which stands as potency in relation to existence, and which we call essence."

In indirect proof, Krapiec refers to the principle of probatio ad absurdum and points out that by identifying essence with existence - that is, by reducing essence to existence - we fall into the trap of pantheism and monism. Because existence, which is the core of being, is subsistent, causeless, the only one, i.e. it is the Absolute. Thus, if every being had existence in and of itself, each would need to be God. Beings would need to be indestructible, eternal, infinite, free of deficiencies, and so on. We see that this is absurd. In turn, by identifying existence with essence (where existence is reduced to essence), we fall into the trap of monism: everything is one." 56

In view of the above, there is a conclusion to be drawn: Every substance with a hylomorphic structure, as well as separated substances having the na-

\footnotetext{
${ }^{54}$ Here, Krąpiec somewhat carelessly uses the Polish term meaning exactly "non-existence", coining the phrase "real non-existence", while what he means is, quite obviously, "something real that is not identical with / different from existence".

${ }^{55}$ KrąieC, Metafizyka [Metaphysics], 419.

${ }^{56}$ This is discussed in more detail in ibid., 423-28.
} 
ture of form, require the act of existence in order to exist. We draw this conclusion on the basis of the analogy of proportions: since in intelligences we discover the composition of essence and existence as the necessary reason of their wholeness and actual existence, then, by analogy, in beings of hylomorphic structure the necessary reason of their wholeness and existence is not only the essence composed of matter and form but also the act of existence that is proportional to their essence. For, in both cases, when we cognitively apprehend their essences, we do not do so with regard to their existence. The relation of essence to existence in these beings is realized in an appropriate proportion: differently in Socrates, differently in Eve, and differently in John (due to the modification of being by the designated matter of Socrates, Eve, and John). This relation of essence to existence is also realized differently in intelligences which differentiate themselves according to the degree of perfection, as they depart in their structure from potentiality and come closer to the pure act.

One has to keep in mind, however - Krąpiec notes - that although on the one hand we emphasize the necessary ordering of essence to existence, thanks to which beings exist, on the other hand "the connection between essence and existence is unnecessary, i.e. existence is not explained by any essential element of being. This unnecessary connection between essence and existence, and the resulting possibility of losing existence, with simultaneous cessation of the existence of the whole being, is expressed by means of predicating per accidens, and not predicating per se; we state that existence is the so-called logical accident in predication and not an actual accident in a really existing being." 57

\subsection{EXISTENCE THAT IS INDEPENDENT BUT NOT SUBSISTENT}

In substances-intelligences, their existence is not absolute, infinite, and boundless, but, while independent, it is limited by their essences (potencies). However, their essences are not related to matter, because they are just forms, and therefore each individual exists as a separate species. Hence Thomas explains that "the intelligences are unlimited from below and limited from above, for they are limited as regards their existence, which they receive from above [from superior ones]; but they are not limited from below [they are not ordered to inferior ones] because their forms are not lim-

\footnotetext{
${ }^{57}$ KrĄPIEC, Metafizyka [Metaphysics], 409.
} 
ited to the capacity of a matter receiving them. And this is why, as has been said, there is not found among such substances a multitude of individuals in one species." 58

In the case of human souls, however, a different situation takes place with regard to the individuation. The soul, although it has an independent (but not absolute) existence, connects in a necessary way with the body. As Thomas explains: "Its individuation depends on the body as upon the occasion for its beginning because it does not acquire its individuated existence except in the body of which it is the actuality, it is not necessary that its individuation be lost when the body is taken away because that existence, since it is absolute, always remains individuated once the soul acquires it by being made the form of this individual body. And this is why Avicenna says that the individuation and multiplication of souls depends on the body as regards its beginning, but not as regards its termination. ... Their proper differences are hidden from us. For even in the case of sensible things, the essential differences themselves are not known; whence they are signified through accidental differences which rise out of the essential ones, as a cause is signified through its effect." ${ }^{, 99}$ Thus, a new concept of human being emerges, in which the soul, while existing independently and being the form of this particular body, is necessarily assigned to the body, and actualizes its individual existence in the body, being its act.

We can draw a few conclusions from the analyses conducted so far: Firstly, the reason of the existence of beings is the necessary relation of their essences (potencies) to the proportional act of existence. Secondly, the reason of the existence of souls and intelligences is also the necessary relationship of their essences to the proportional act of existence. Thirdly, thanks to the acts of existence, substances obtain their independent, but not self-contained existence, and for this reason they indicate the contingent (unnecessary) character of their actual existence. The discovered common composition of beings, i.e. that of essence and existence, as well as their contingency, reveal the openness and at the same time the questionability of being with regard to the reason of its existence. Fourthly, only such a thing can exist in and of itself, "whose essence is its very existence."

\footnotetext{
${ }^{58}$ Thomas Aquinas, On Being and Essence, Cap. 4, no. $92 \mathrm{f}$.

${ }^{59}$ Ibid., no. $93 \mathrm{f}$.
} 


\section{WHY IS THE FIRST CAUSE IPSUM ESSE?}

There must be the First Cause of the existence of composite beings (material and non-material), since these beings have been identified as being composed of essence (potency) and existence, and therefore contingent and unnecessary in their existence. However, the act of existence of these beings is not necessarily related to their essence and is not deductible from that essence. If such beings exist, and they do so not-necessarily, there must be a Cause which is the reason for their coming into being and their continued existence; a Cause which is not conditioned by anything. And such a Cause is God, who is Ipsum Esse, and who is not conditioned by anything, and is not relativized to anything. Such is the conclusion Thomas draws as a consequence of the new interpretation of the understanding of being and essence. God is Existence, and there is no other existence besides Him. As we would say, God is Light, and there is no other light than Him. The word "Absolute" indicates this unconditional and non-relative character, which is derived from two words: the pronoun solutus and the prefix $a b$. They signify a being that is not bound to anything, that is free from all references, relationships. Hence the act of creation is reduced to two "activities": the introduction of beings into existence by an act of intellect and will ex nihilo (producere rei in esse); and the introduction of the first references, relations (constitutio ipsa dependentia) ${ }^{60}$ It is here that the radical transcendence of God in relation to the world and its constituent beings is revealed, which have God-given existence in the act of creation and are relativized to the corresponding essences. Thus, beings do not have a divine existence, because it would constitute pantheism, but have an existence relativized to their own essences: John has the existence relativized to human nature; the horse has the existence relativized to animal nature, an angel to angelic nature, and so forth.

This radical difference in the Divine Existence is also due to the fact that we cannot place it in any kind or species; nor can we add anything to it because it is not composite; it is unique and individual; it is in the highest degree perfection and the source of all perfection (just as it is the source of all existence). "The seed theory of God-as Krapiec explains this fragment of the text - is only an emphasis on the consequences of the adopted new the-

\footnotetext{
${ }^{60}$ Thomas Aquinas, Summa Contra Gentiles (Taurini: Ex Officina Libraria Marietti, 1967), Lib. II, Cap. 16 and 18.
} 
ory of being - being that consists of essence and existence. God - the Pure Existence - is at the same time the First Being; the ultimate Reason of being and the ultimate Perfectness itself, insofar as everything that is perfect in being is concentrated in existence as an act of being." ${ }^{\prime \prime 1}$

Being whose essence is existence abolishes its relational character and relativity; it is Ipsum Esse, that is, it is [pure] existence, and everything else has some existence defined by the essence and relativized to the essence. Such a Being, in which the essence is its existence, is one and is the First Being. There is one, because there is no reason of plurality in it. "If we posit a thing which is existence alone, such that this existence is subsistent, this existence will not receive the addition of a difference because it would no longer be existence alone, but existence plus some form." ${ }^{\circ 2}$

\section{CONCLUSION: \\ THE FIRST CAUSE (CREATOR) THAT BESTOWS EXISTENCE}

The First Cause is a substance whose essence is its unconditional existence. It is Ipsum Esse, Thomas will say. "It cannot be - he will remark after finishing his considerations on being and essence - that the existence of a thing is caused by the form or quiddity of that thing." ${ }^{63}$ A paradox would then occur: something [that there is], namely a form or an essence, would be the cause of itself and "something would bring itself into existence, which is impossible." ${ }^{64}$ The conclusion Thomas draws is obvious: "It is therefore necessary that every such thing, the existence of which is other than its nature, have its existence from some other thing." In turn, that which has its existence due to something else indicates that which exists "by virtue of itself, it is necessary that there be some thing which is the cause of the existence of

\footnotetext{
${ }^{61}$ Tomasz z AKwinu [Thomas Aquinas], O bycie $i$ istocie [On being and essence], ch. 5, p. 38 , footnote 56 .

${ }^{62}$ The reason of plurality of composite beings dwells on the side of essence composed of form and designated matter, whether by species or genus. In beings that are intelligences, in which there is no composition of form and matter (i.e. those beings are non-relational), the differentiation is expressed in the fact that there is one that is single and unrelative (non-relational), while others are "received into something; for example, if there were a separated heat, it would by virtue of its very separation be other than heat which is not separated." THOMAS AQuinas, On Being and Essence, Cap. 3, no. 78.

${ }^{63}$ Ibid., no. 80

${ }^{64}$ Ibid.
} 
all things because it is existence alone. Otherwise, there would be an infinite regress among causes, since every thing which is not existence alone has a cause of its existence." 65

Thus, we arrive at a Being in which "there is no longer a composition of essence and existence as potency and act of a particular being, but only an act of existence itself - a "pure" existence that constitutes being in the most appropriate and complete sense. This being, however, is not directly cognizable to us; it merely emerges before us as the reason of existence of the entire reality. That, Krapiec says, is the Absolute. ${ }^{\prime 66}$ The First Cause understood in this way, by virtue of the fact that it is itself existence alone, is the Creative Cause. Its specific character as a cause is expressed in bestowing existence upon beings by bringing them into existence ex nihilo (productio rei in esse), and constituting the first intra- and inter-being relations (constitutio ipsa dependentia). ${ }^{67}$ Only in this way can we avoid the absurdity in explaining the existence of contingent and unnecessary beings, which would otherwise be manifest in the fact that - as Aristotle would have said, and Thomas would have confirmed - we were explaining existence by means of nonexistence.

Translated from Polish by Maciej B. Stępień

\section{BIBLIOGRAPHY}

AristotLE. Categories. Translated by E. M. Edghill. Adelaide: University of Adelaide Library, 2015. Text online: https://ebooks.adelaide.edu.au/a/aristotle/categories/. Accessed August $11^{\text {th }}$, 2019.

AristotLe. Metaphysics. Translated by W.D. Ross. Adelaide: University of Adelaide Library, 2000. Text online: https://ebooks.adelaide.edu.au/a/aristotle/metaphysics/book4.html. Accessed August $\left.11^{\text {th }}, 2019\right]$.

Kerr, Gaven, O.P. Aquinas's Way to God. The Proof in "De Ente et Essentia. Oxford: Oxford University Press, 2015.

KrĄPIEC, Mieczysław A. Metafizyka. Zarys teorii bytu [Metaphysics: An outline of the theory of being]. Lublin: TN KUL, 1978.

MARyNiARCZYK, Andrzej. Dlaczego stworzenie „ex nihilo” [Why Creation ex nihilo?]. Lublin: PTTA, 2018.

\footnotetext{
${ }^{65}$ Ibid.

${ }^{66}$ KRĄPIEC, Metafizyka [Metaphysics], 413.

${ }^{67}$ More on this topic in Andrzej MARYNIARCZYK, Dlaczego stworzenie „ex nihilo” [Why Creation ex nihilo?] (Lublin: PTTA, 2018), 62-73.
} 
SEŃKo, Władysław. "Wstęp [Introduction]." In Thomas Aquinas. Byt i istota [Being and Essence]. Translated and commented by Władysław Seńko, 13-24. Kęty: Wydawnictwo Marek Derewiecki, 2009.

Thomas Aquinas, On Being and Essence. Translated by Armand A. Maurer. Toronto, Canada: Pontifical Institute of Mediaeval Studies, 1965. Full text online: https://dhspriory.org/ thomas/DeEnte\& Essentia.htm. Accessed August $11^{\text {th }} 2019$.

Thomas Aquinas. Summa Contra Gentiles. Taurini: Ex Officina Libraria Marietti, 1967.

Tomasz Sutton [Thomas of SutTon]. De esse et essentia. Translated by Piotr Kordula. Introdustion by Dawid Lipski. Warszawa: Wydawnictwo von borowiecky, 2018.

Tomasz z Akwinu, św. [Thomas Aquinas, St.]. O bycie i istocie [On being and essence]. Translated by Mieczysław A. Krąpiec. Lublin: RW KUL, 1994.

\section{"PARVUS ERROR IN PRINCIPIO MAGNUS EST IN FINE": THOMAS AQUINAS'S REINTERPRETATION OF THE UNDERSTANDING OF BEING AND ESSENCE AS THE BASIS FOR THE DISCOVERY OF THE FIRST CAUSE AS IPSUM ESSE}

S u m m a r y

In this article, the author notes that Thomas Aquinas, in his brief work entitled De Ente et Essentia, proved that at the base of understanding the world, the human being, and God in particular, there is our understanding of being and its essence. When we make a small mistake at the beginning (parvus error in principio) in our understanding of being and its essence, it will turn to be a big one in the end (magnus in fine). And what is "at the end" of our knowledge is the discovery of the First and Ultimate Cause of all things, known as: Ipsum Esse, God, the Absolute, The Most Perfect Substance, on whom everything depends, and who depends not on anything else. These present inquiries about the proper understanding of being and its essence are aimed at formulating proof of the necessity of existence of a Being that is the First Cause, and which, existing as Ipsum Esse, is the source and reason of existence of all beings. Without these inquiries, the proof itself would be incomprehensible, and more importantly it would be a purely a priori one (i.e., ontological). Furthermore, without the existential conception of being, which Thomas first formulated, one could not discover the First Cause which, as Ipsum Esse, is the source of the existence of every being. This issue seems to have escaped the attention of the author of the book Aquinas's Way to God. The Proof in "De Ente et Essentia."

Translated from Polish by Maciej B. Stępień

\section{„MAŁY BŁĄD NA POCZĄTKU WIELKIM JEST NA KOŃCU”: TOMASZOWA REINTERPRETACJA ROZUMIENIA BYTU I ISTOTY PODSTAWĄ ODKRYCIA PIERWSZEJ PRZYCZYNY JAKO IPSUM ESSE}

\section{Streszczenie}

W niniejszym artykule autor zwraca uwagę, że Tomasz z Akwinu w swoim dziełku, noszącym tytuł De ente et essentia, udowodnił, że u podstaw rozumienia świata, człowieka, a w sposób szczególny Boga stoi rozumienie bytu i jego istoty. Gdy popełnimy mały błąd na początku (parvus error in principio) $\mathrm{w}$ rozumieniu bytu i jego istoty, to okaże się on wielkim na końcu (magnus in fine). A tym, co jest „na końcu” naszego poznania, jest właśnie odkrycie Pierwszej i Ostatecznej Przyczyny wszechrzeczy, określanej jako Ipsum Esse, Bóg, Absolut, Substancja 
Najdoskonalsza, od której wszystko zależy, a Ona od nikogo innego. Zapowiedziane dociekania nad właściwym rozumieniem bytu i jego istoty mają na celu doprowadzić do sformułowania dowodu o konieczności istnienia Bytu jako Pierwszej Przyczyny, która będąc Ipsum Esse, jest źródłem i racją istnienia wszystkich bytów. Bez tych dociekań sam dowód byłby niezrozumiały, a co ważniejsze - byłby czysto aprioryczny (w sensie ontologiczny). Ponadto bez egzystencjalnej koncepcji bytu, którą po raz pierwszy sformułował Tomasz, nie można by dojść do odkrycia Pierwszej Przyczyny, która jako Ipsum Esse jest źródłem istnienia każdego bytu. Ten też problem zdaje się umknął uwadze autora książki Aquinas's Way to God. The Proof in „,De Ente et Essentia”.

Key words: being; essence; God; Ipsum Esse; proof; metaphysics.

Słowa kluczowe: byt; istota; Bóg; Ipsum Esse; dowód; metafizyka.

Informacje o Autorze: Prof. dr hab. ANDRZEJ MARYNIARCZYK SDB - profesor filozofii w Katolickim Uniwersytecie Lubelskim Jana Pawła II, kierownik Katedry Metafizyki; adres do korespondencji — e-mail: maryniar@kul.pl; ORCID: https://orcid.org/0000-0001-6535-5089. 